\title{
CONDITION FACTOR IN NINE SPECIES OF FISH OF THE CHARACIDAE FAMILY IN THE UPPER PARANÁ RIVER FLOODPLAIN, BRAZIL
}

\author{
LIZAMA, M. de los A. P. and AMBRÓSIO, A. M. \\ Programa de Pós-graduação em Ecologia de Ambientes Aquáticos Continentais, Universidade Estadual de \\ Maringá, DBI/Nupélia, Avenida Colombo, 5790, Bloco G90, CEP 87020-900, Maringá, Paraná, Brazil \\ Correspondence to: Maria de los Angeles P. Lizama, Universidade Estadual de Maringá, Avenida Colombo, 5790, \\ Bloco G90, CEP 87020-900, Maringá, Paraná, Brazil, e-mail: abrapoa@ wnet.com.br \\ Received March 14, 2000 - Accepted December 18, 2000 - Distributed February 28, 2002
}

(With 12 figures)

\begin{abstract}
The condition factor for nine species of tropical freshwater fish of the Characidae family in the upper Paraná River floodplain is described. Fish were caught over a period of 12 months (February 1993 to March 1994). Knowledge of the nine species is important for adequate management and maintenance of the biological equilibrium of the ecosystem.
\end{abstract}

Key words: condition factor, Characidae, floodplain, Paraná River.

\section{RESUMO}

\section{Estudo do fator de condição de nove espécies de peixes da família Characidae na planície de inundação do alto rio Paraná, Brasil}

O fator de condição foi descrito para 9 espécies de peixes da família Characidae de água doce tropical na planície de inundação do alto rio Paraná. Os peixes foram capturados em um período de 12 meses (de fevereiro de 1993 a março de 1994). O conhecimento dessas nove espécies é extremamente importante para a obtenção de um adequado manejo e manutenção do equilíbrio biológico do ecossistema.

Palavras-chave: fator de condição, Characidae, planície de inundação, rio Paraná.

\section{INTRODUCTION}

Knowledge of quantitative aspects such as weight-length relationship, condition factor, growth, recruitment, and mortality of fishes is an important tool for the study of fishing biology, mainly when the species lies at the base of the higher food web.

In fish, the factor of condition $(\mathrm{K})$ reflects, through its variations, information on the physiological state of the fish in relation to its welfare. From a nutritional point of view, there is the accumulation of fat and gonadal development (Le Cren, 1951). From a reproductive point of view, the highest $\mathrm{K}$ values are reached in some species (Angelescu et al., 1958). $\mathrm{K}$ also gives information when comparing two populations living in certain feeding, density, climate, and other conditions; when deter- mining the period of gonadal maturation; and when following up the degree of feeding activity of a species to verify whether it is making good use of its feeding source (Weatherley, 1972).

The study of the condition factor is thus important for understanding the life cycle of fish species and contributes to adequate management of these species and, therefore, to the maintenance of equilibrium in the ecosystem.

The aim of this research is to follow a series of investigations to understand the structure of the main foraging species of the floodplain. The condition factor of 9 species of the Characidae family will be analyzed: Astyanax altiparanae Garutti \& Britski, 2000; Astyanax schubarti (Britski, 1964); Aphyocharax nasutus (Ahl, 1936); Cheirodon notomelas (Eignmann, 1915); Hyphessobrycon 
callistus (Boulenger, 1900); Hemigrammus marginatus (Ellis, 1911); Moenkhausia intermedia (Eigenmann, 1908); Moenkhausia sanctae-filomenae (Steindachner, 1907) and Roeboides paranensis (Pignalberi, 1975).

\section{MATERIALS AND METHODS}

Fishes were collected monthly from March 1993 to February 1994 in the floodplain of the upper Paraná River (Fig. 1) by $50 \mathrm{~m}$ long seining nets with $0.8 \mathrm{~cm}$ mesh $(0.5 \mathrm{~cm}$ mesh in the bag) and by gillnets with different mesh sizes.

Astyanax altiparanae, A. schubarti and $R$. paranensis were the only ones to be caught in nets with smaller mesh because they are small-sized species.

Fishes were identified at the species level. Total length (TL; cm), standard length (SL; cm), and total weight (TW; g) were obtained. Data on sex and stage of gonadal immaturity in some individuals were also obtained.

The value of $\mathbf{b}$ from the weight-length relation (Lizama et al., 1999), described in Table 1, was employed in calculating the condition factor. Individual values of the condition factor were obtained through the formula $\mathrm{K}=\mathrm{TW} / \mathrm{SL}^{\mathrm{b}}$. Monthly means were calculated from individual values. Separation by sex was not possible and the grouped form was used.

Species data from a bibliographical survey were also employed. They deal with aspects on reproduction, feeding, and population structure in other environments. Such data were a help in understanding species behavior.

The few data sampled on sex and stage of gonadal maturity somewhat elucidated hypotheses on the life cycle of these species.

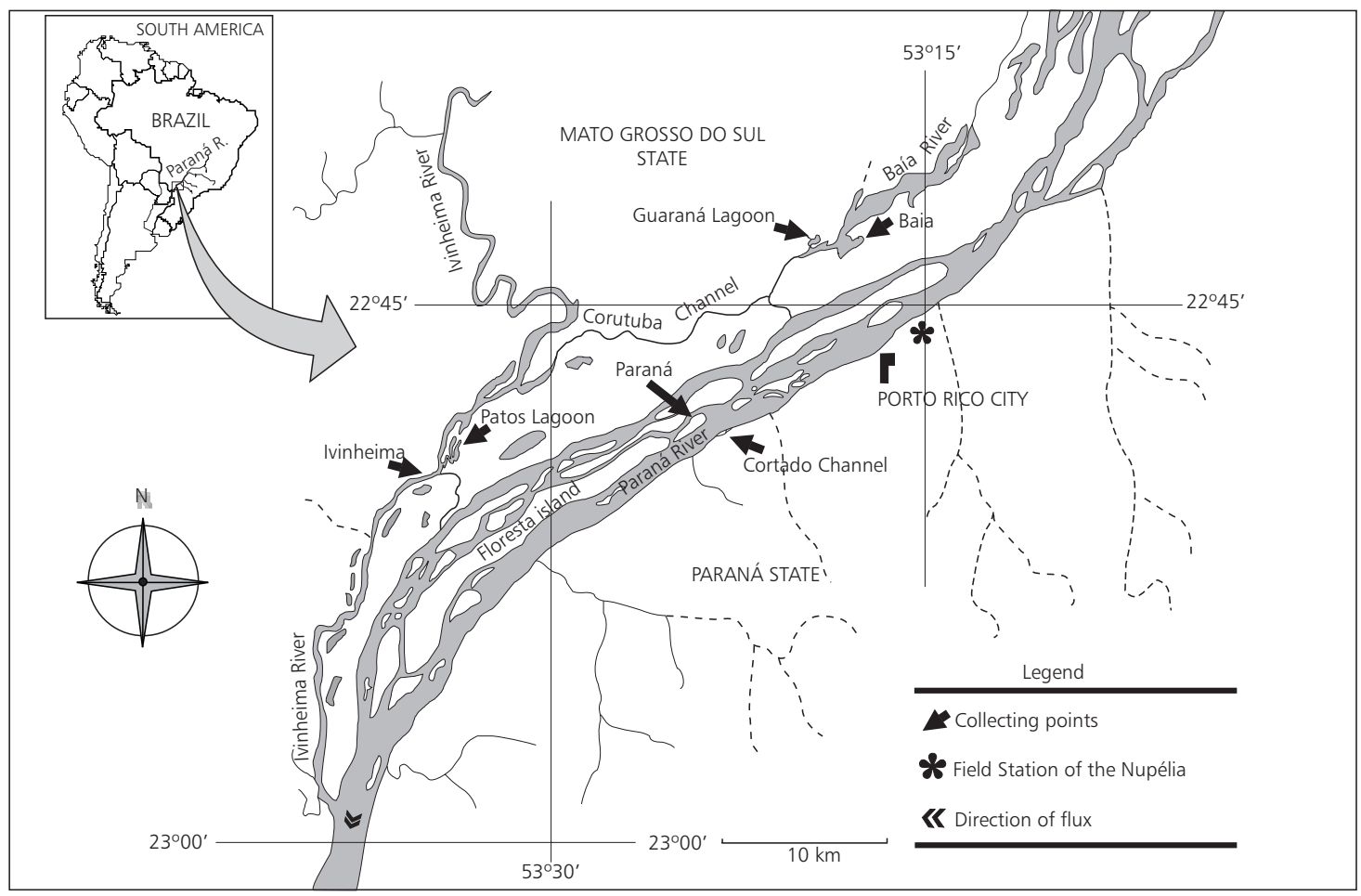

Fig. 1 - Area studied. 
TABLE 1

Weight/length relationship values of nine species in the floodplain of the upper Paraná River. ( $N$ = numbers of individuals used.)

\begin{tabular}{|l|c|c|c|c|}
\hline \multirow{2}{*}{ Species } & \multicolumn{4}{|c|}{ TW/SL Relationship } \\
\cline { 2 - 5 } & N & A & b & r \\
\hline Astyanax altiparanae & 1832 & 0.02348 & 3.13 & 0.94 \\
\hline Astyanax schubarti & 662 & 0.0179 & 3.11 & 0.94 \\
\hline Aphyocharax nasutus & 1393 & 0.0162 & 2.89 & 0.94 \\
\hline Cheirodon notomelas & 755 & 0.0199 & 3.09 & 0.92 \\
\hline Hyphessobrycon callistus & 1086 & 0.0183 & 3.10 & 0.90 \\
\hline Hemigramus marginatus & 1712 & 0.0145 & 3.14 & 0.91 \\
\hline Moenkhausia intermedia & 1641 & 0.0176 & 3.02 & 0.96 \\
\hline Moenkhausia sanctae-filomenae & 295 & 0.0204 & 3.21 & 0.91 \\
\hline Roeboides paranensis & 2287 & 0.0104 & 3.21 & 0.94 \\
\hline
\end{tabular}

\section{RESULTS AND DISCUSSION}

The condition factor is an index reflecting interactions between biotic and abiotic factors in the physiological condition of fishes. It shows the population's welfare during the various stages of the life cycle (Angelescu et al., 1958). In the case of Puntius puntius (Bhatnagar, 1963) and Micropogonias furnieri (Vazzoler \& Braga, 1983), the condition factor decreases at the start of the spawning period due to very high metabolic rates. There is normally a gradual increase in the condition factor during the reproductive period and normalization occurs immediately afterwards. Vazzoler \& Vazzoler (1965) state that the condition factor does not merely reflect the feeding condition of the adult stage, but includes the state of gonadal development, based on the consumption of fat reserves during the spawning period. Similar results have been obtained by Martins-Juras (1980) for M. furnieri.

Vazzoler \& Braga (1983) showed that in Cynoscion jamaicensis, there was a certain constancy in the condition factor values in relation to the length of mature specimens during a one-year period. Vazzoler \& Vazzoler (1965) had already observed that in Sardinella brasiliensis this constancy did not exist, as the young extract of this species presented $\mathrm{K}$ values greater than those of the adult extract. Braga \& Gennari Filho (1988) revealed that the condition factor and the quantity of accumulated fat follow the rhythm of the reproductive process. At the start of this process, high values are the result of fat accumulation in the preceding phases; a gradual $\mathrm{K}$ decrease occurs together with decrease in fat (during this period the reproductive intensity is very low). Afterwards, there is a gradual increase in accumulated fat and $\mathrm{K}$ values, suggesting a preparatory span for a new reproductive period.

Employing body weight (total weight minus gonad weight), Braga \& Gennari Filho (1990) showed that monthly values decreased at the highest reproductive level. This indicates that during this period the fish often does not feed, but uses lipid reserves necessary for spawning. The same authors stated that generally there is a decrease in feeding activity during the reproductive period, followed by a fall in the mean value of the condition factor and in the monthly percentage frequency of visceral fat accumulated during these months.

As for the condition factor of Astyanax altiparanae, $\mathrm{K}$ varies about 0.024 . The lowest value was found in September and the highest in April (Fig. 2). Results suggest that in September the species starts the reproductive period. On the other hand, in April, with $\mathrm{K}$ at the highest level, individuals had already recovered. These data coincide with those of Vazzoler \& Braga (1983) and Vazzoler (1996). 

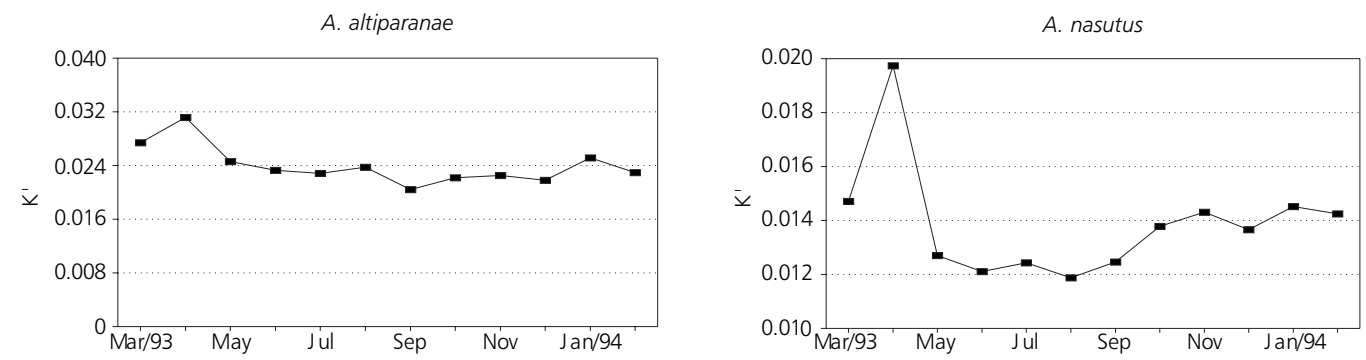

A. schubarti
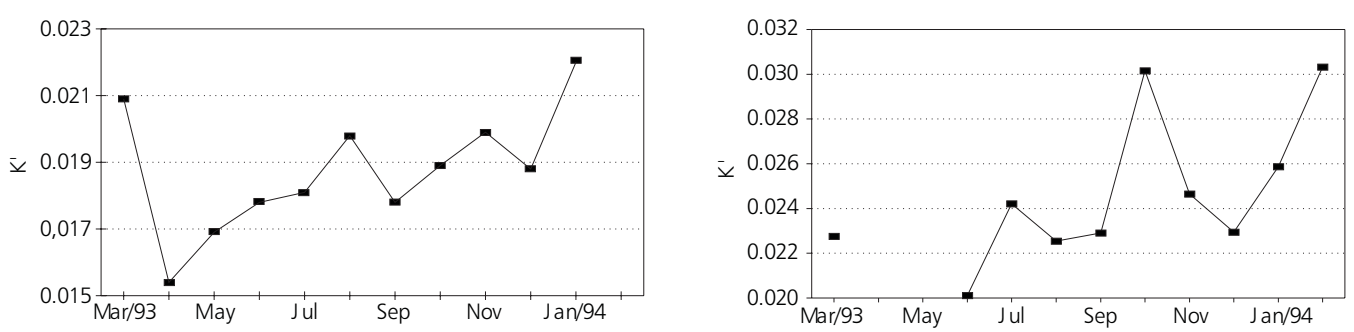

H. callistus

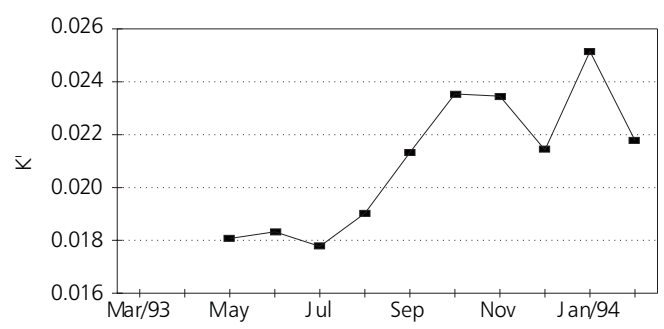

H. marginatus

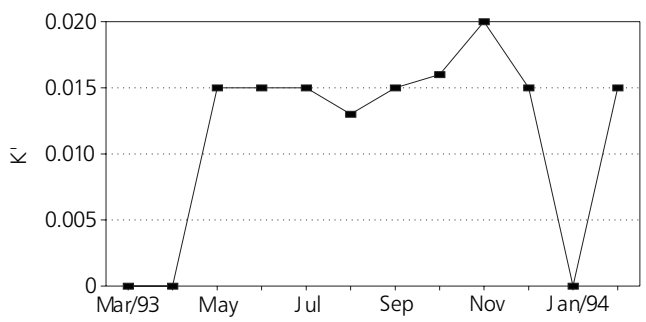

M. intermedia
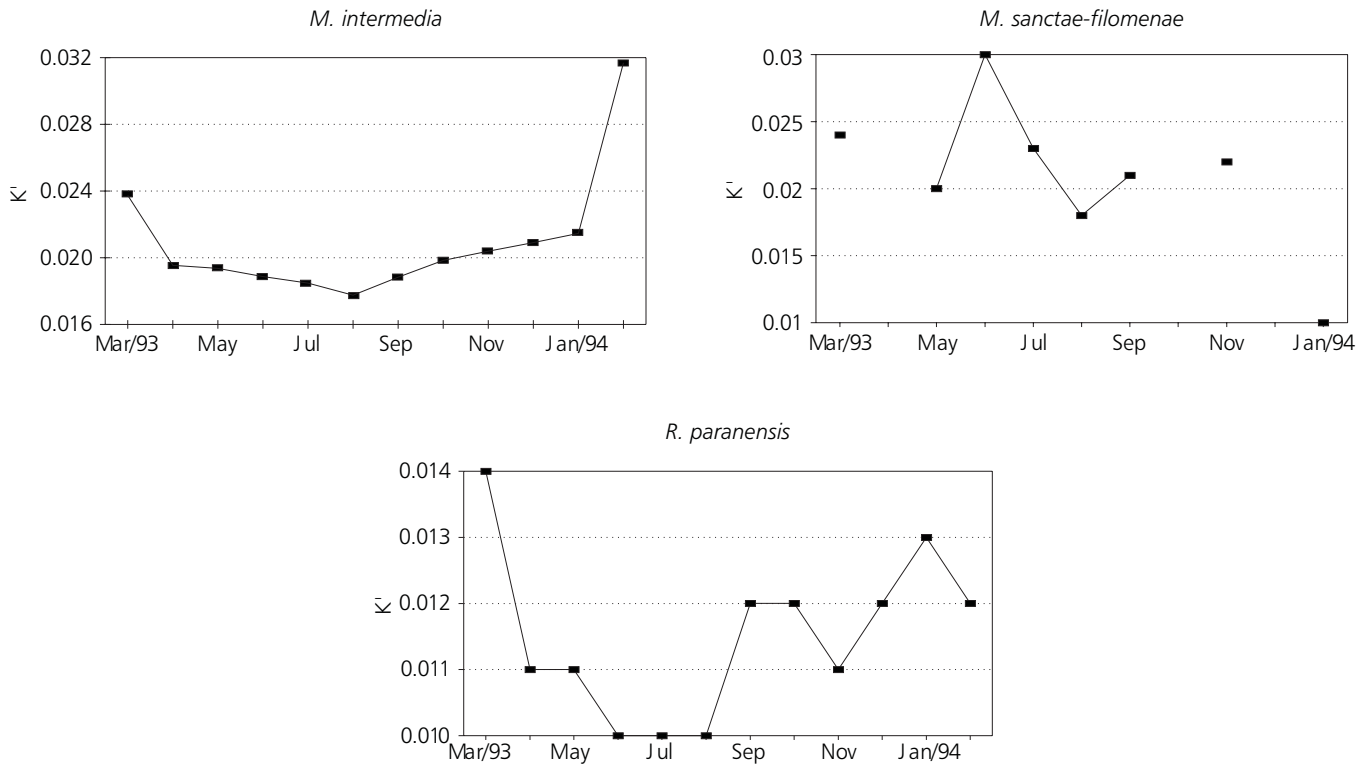

Fig. 2 - Monthly condition factor for nine Characidae species in the floodplain of the upper Paraná River. 
Figueiredo-Garuti \& Garuti (1991) observed that the species has three reproductive periods: August/September, November/January, and March. They also state that the lowest $\mathrm{K}$ value occurs in the beginning of the reproductive period and the highest at its end. Fig. 3 shows that the species recruits throughout the year, which corresponds to results mentioned above.

A. altiparanae

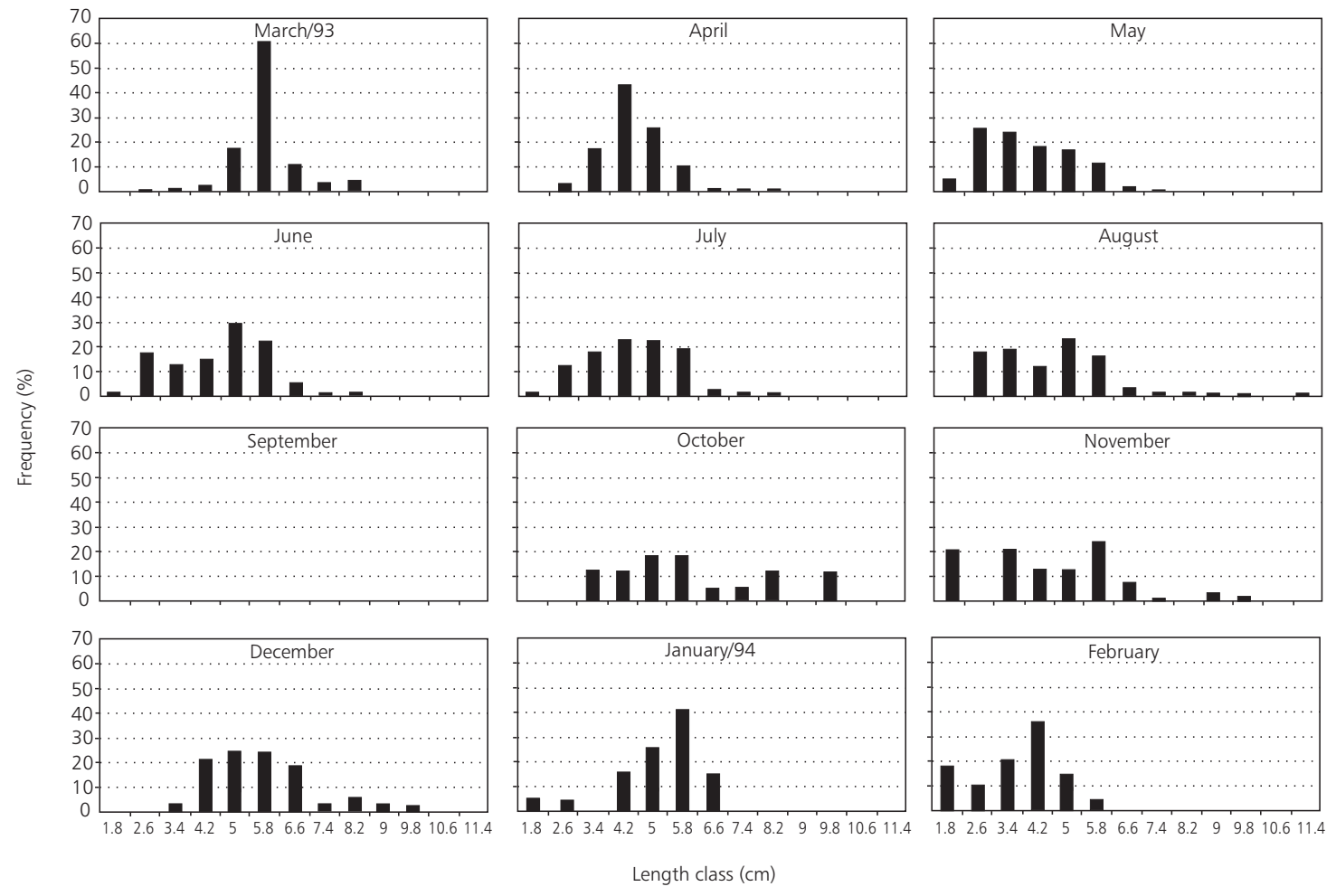

Fig. 3 - Length frequency distribution of Astyanax altiparanae in the floodplain of the upper Paraná River.

Aphyocharax nasutus has a monthly variation in $\mathrm{K}$ values similar to that of the genus Astyanax. The lowest value occurs in August, probably during the recovery period of the species. Condition value increases in September and oscillates around 0.014, which may indicate the start of the reproductive period. The highest $\mathrm{K}$ value occurs in April (Fig. 2 ), possibly explaining why only one individual was captured during the month. Results may be confirmed from Fig. 4 which shows that introduction of juveniles occurred between May and June, but starting from August.

Results similar to those of the present authors were obtained for Astyanax schubarti by Rodrigues et al. (1995). Since the species has its highest condition factor in December-January, it has been suggested that specimens develop and prepare for reproduction during this period. According to these authors, the species has annual and parceled spawning with continuous recruitment of juveniles. Results shown in Fig. 5 are not so clear on this point when compared with those of Rodrigues et al. (1995), which may be explained if one considers that the population is essentially composed of juveniles (only $3.2 \%$ of sampled individuals with lengths greater than those of $\mathrm{L}_{50}$ ).

During the whole year, Cheirodon notomelas presented low K values. The highest values oc- 
curred in October (Fig. 2). This suggests that during this period the species would be prepared for reproduction, but would probably spawn throughout the whole year as well, as perhaps confirmed by the monthly length frequency distribution (Fig. 6) showing that the shorter specimens are introduced into the environment starting in April.

Hyphessobrycon callistus presented increasing $\mathrm{K}$ values throughout the whole year. The lowest values occurred between May and July (especially the latter), possibly signaling the end of the reproductive period. From July on, $\mathrm{K}$ increased until October and oscillated until February. The highest value occurred in January (Fig. 2), the period of probable spawning peak. Fig. 7 corroborates this, since it shows the introduction of first length classes in February and suggests recruitment of juveniles in the floodplain. The absence of specimens in March and April may be explained by sampling problems or because of some biotic or abiotic factor. Starting from May, the first length classes of this species may already be found, perhaps a standard for these Characid species.

Concerning Hemigrammus marginatus, the lowest value of the condition factor occurs in $\mathrm{Au}-$ gust and may mean the end of the reproductive period. From September, the $\mathrm{K}$ value gradually increases, reaching its highest value in November (Fig. 2). This indicates that the species is prepared for reproduction sometime before that period ( $\mathrm{Au}$ gust). It should be emphasized that during the other months the $\mathrm{K}$ value remained constant with only slight variation. Although no specimen was caught between March-April and January, Fig. 8 shows the presence of the smallest length classes, especially from May to August, supposedly a spawning period, too.
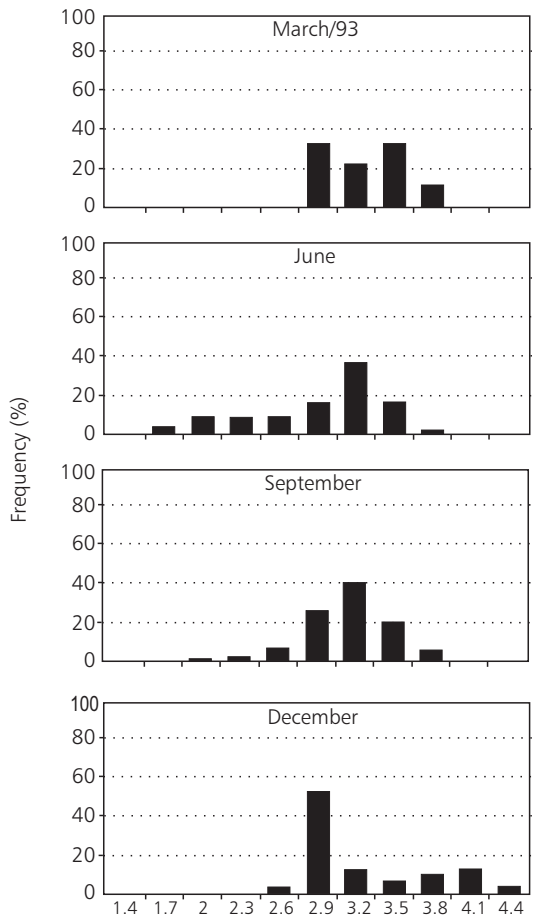
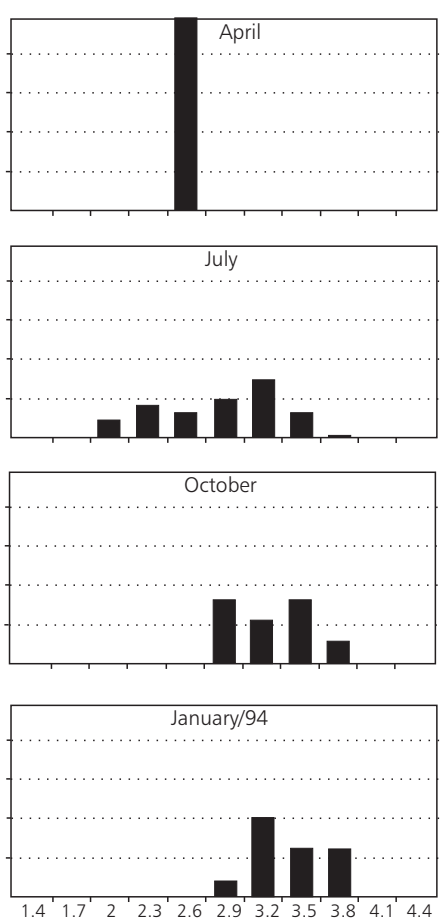

Length class $(\mathrm{cm})$
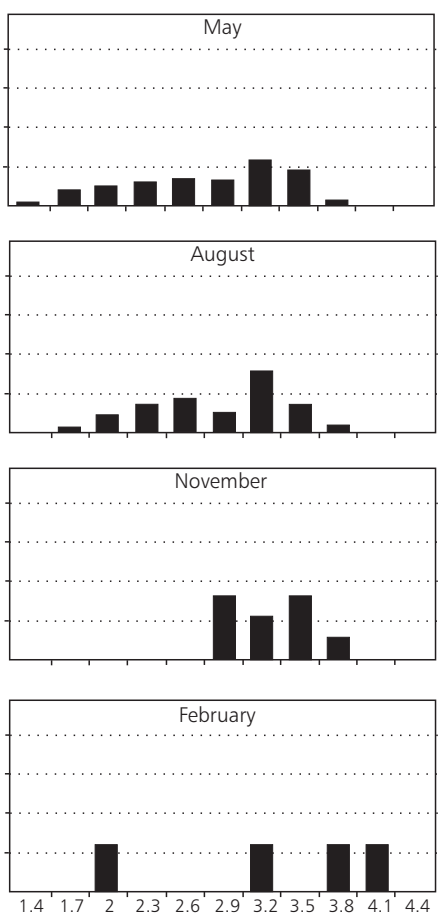
A. schubarti
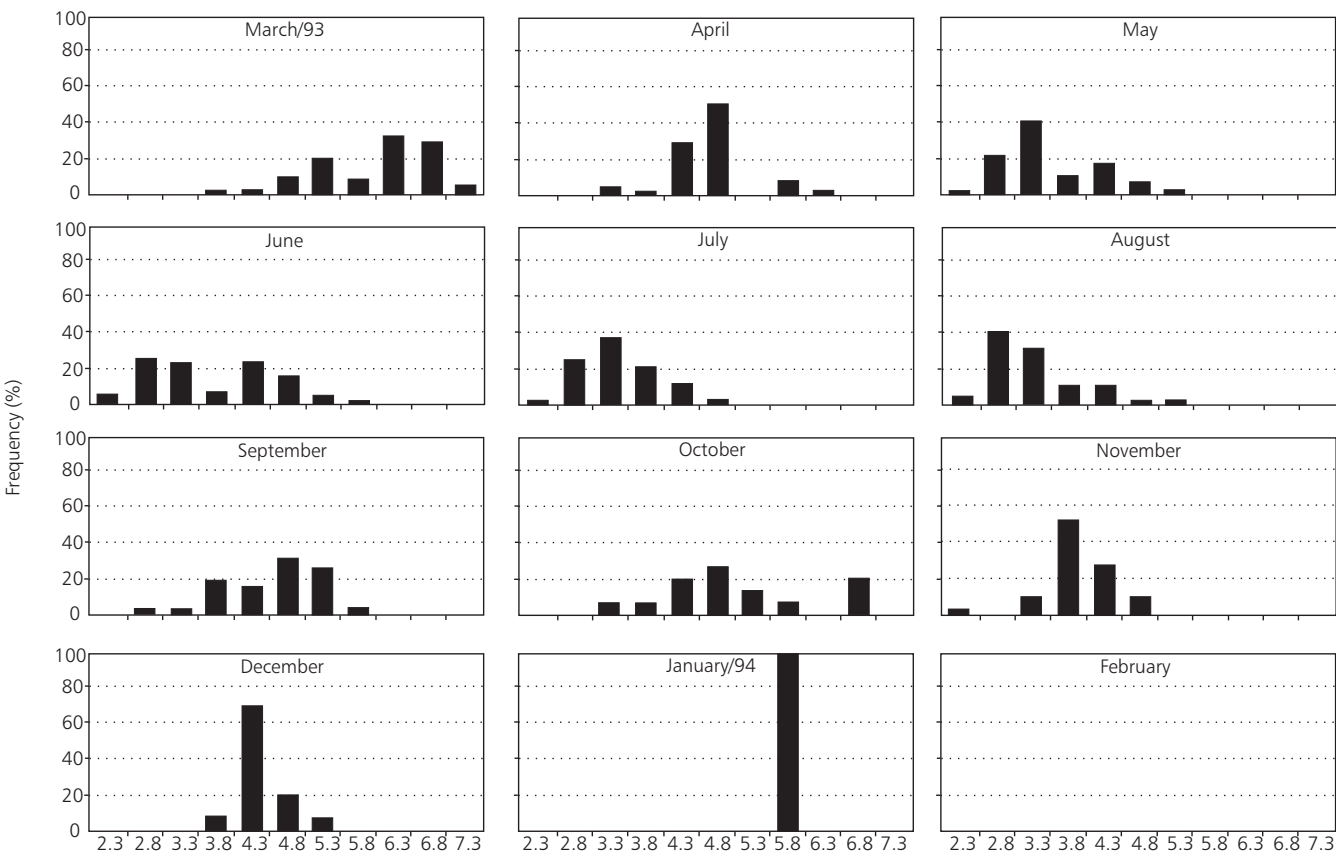

Length class $(\mathrm{cm})$

Fig. 5 - Length frequency distribution of Astyanax schubarti in the floodplain of the upper Paraná River.

C. notomelas

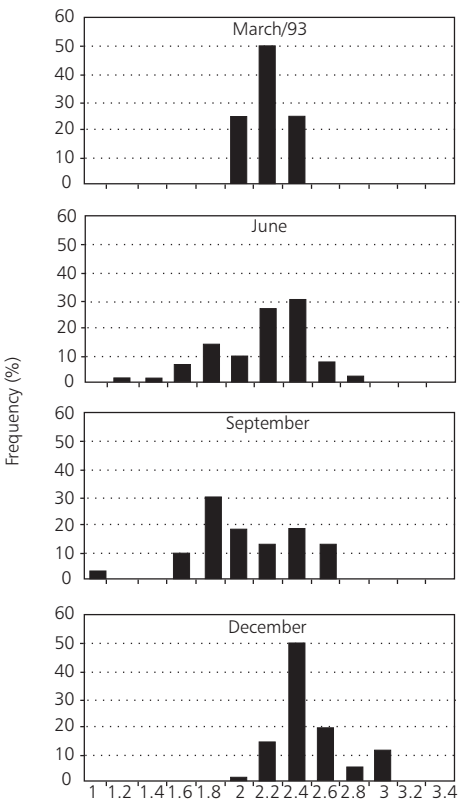

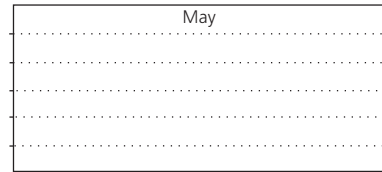
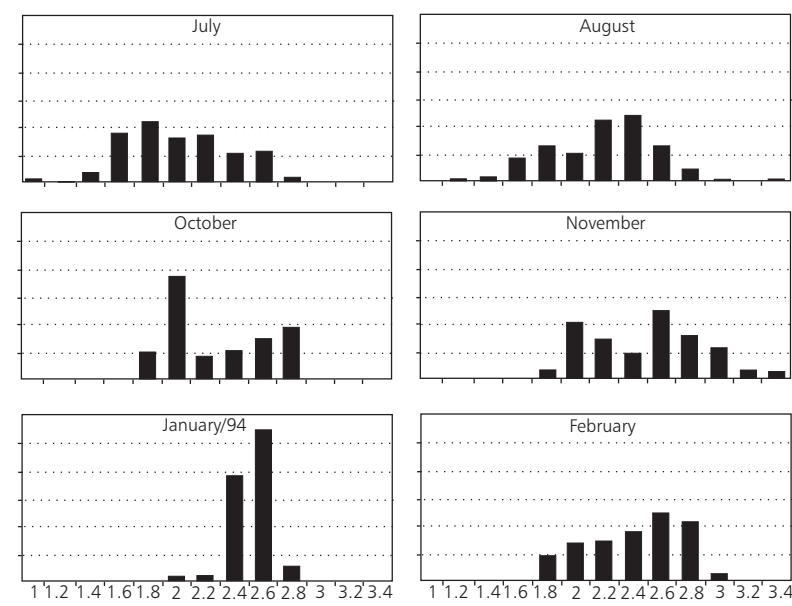

Length class $(\mathrm{cm})$

Fig. 6 - Length frequency distribution of Cheirodon notomelas in the floodplain of the upper Paraná River. 


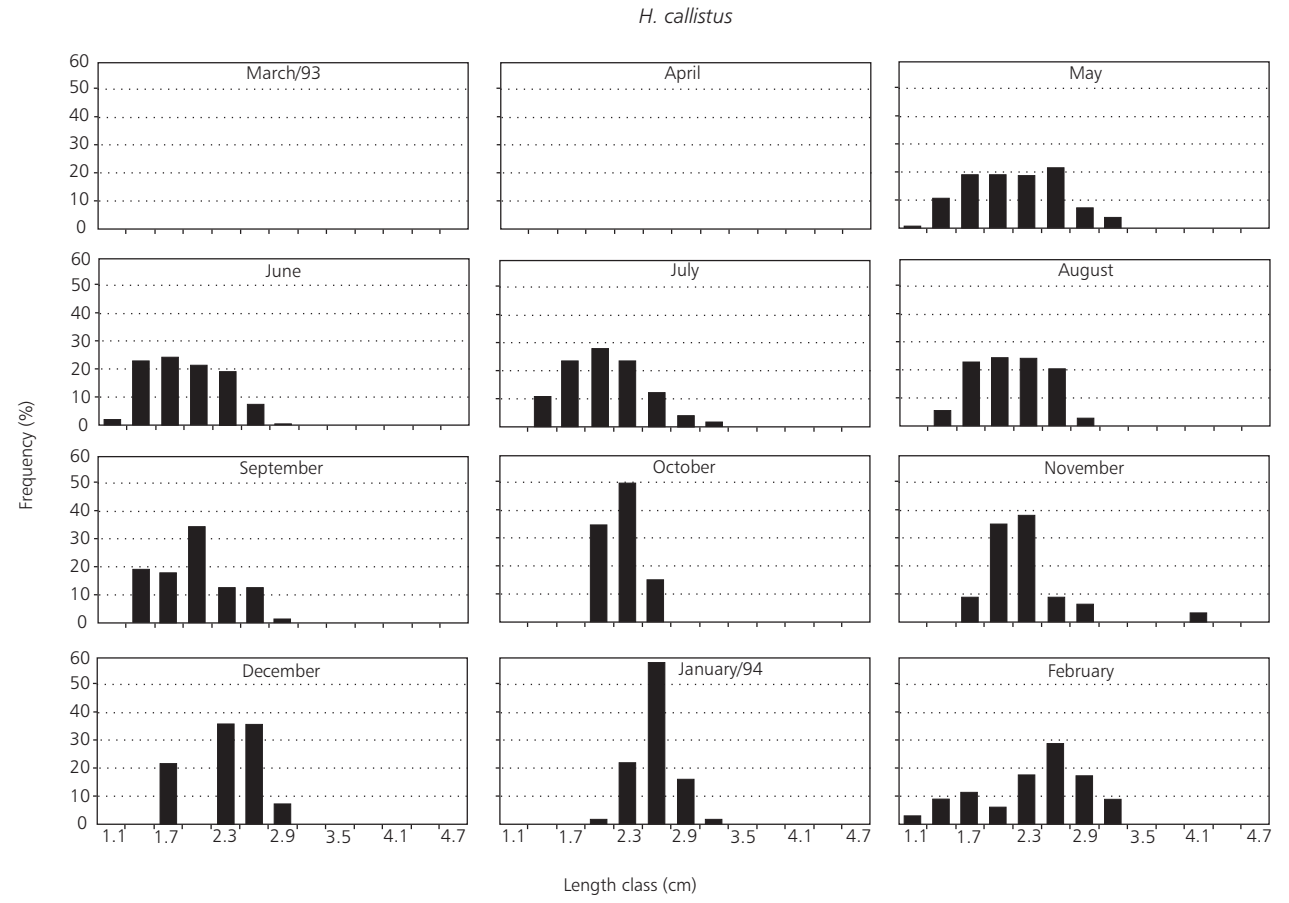

Fig. 7 - Length frequency distribution of Hyphessobrycon callistus in the floodplain of the upper Paraná River.

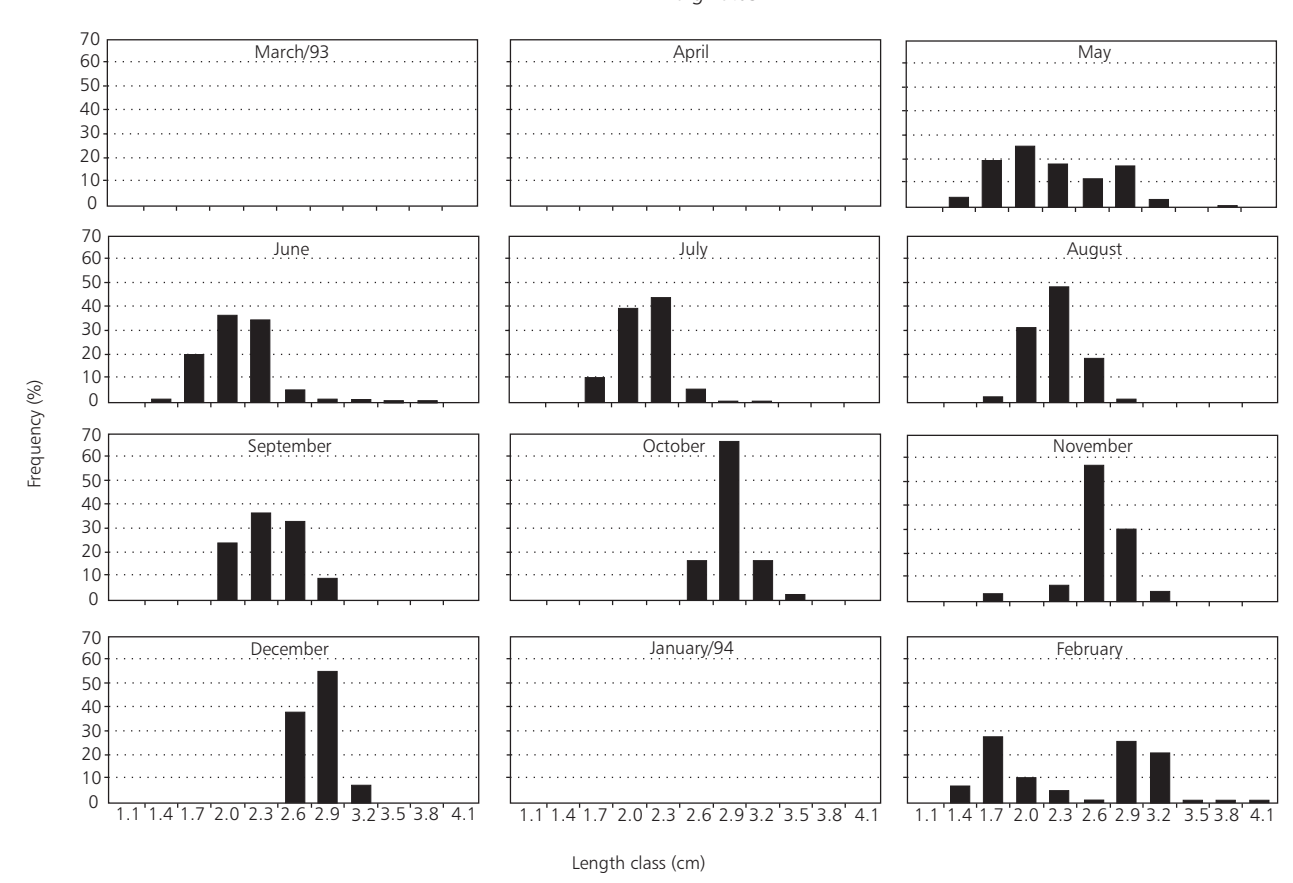

Fig. 8 - Length frequency distribution of Hemigrammus marginatus in the floodplain the upper Paraná River. 
Rodrigues et al. (1991) stated that in the case of Moenkhausia intermedia, the species has the same spawning type as that of Astyanax altiparanae, with higher spawning intensity in October and November. Monthly condition factors show that values oscillate throughout the year (Fig. 2). Values are lowest between July and September, mainly in August. In these months, the species ends a reproductive term. The condition factor increases starting from September (the reproductive period is resumed), reaching its highest values in February and March. Results agree with data from Vazzoler (1996) and Rodrigues et al. (1991). Fig. 9 shows that entrance of recruits occurs practically throughout the year. Braga \& Gennari Filho (1990) state that the species has two spawning peaks.

Moenkhausia sanctae-filomenae has the lowest $\mathrm{K}$ values in January and highest in June (Fig. 2). Fig. 10 shows results with an introduction of recruits during May and low frequency in September and February, even though individuals with less than $2.1 \mathrm{~cm}$ were not caught in the dragnets. Results suggest that the species spawns between September and June, i.e., between the months in which values of the condition factor are highest.
Concerning Roeboides paranensis, values of the monthly condition factor (Fig. 2) suggest that those of the species are highest between January and March (highest in March). During this period, spawning occurs. With lowest $\mathrm{K}$ values between June and August, it seems likely that individuals would be recovering from the previous spawning. Fig. 11 shows individuals in all length classes during the year, suggesting continuous recruitment in the area under analysis.

In the case of the condition factor per length class (Fig. 12), the present authors affirm that, as a general rule, the highest values of the condition factor occur in the lowest lengths, or rather, in the juvenile classes. Vazzoler (1996) confirmed that lowest $\mathrm{K}$ values during the more developed gonadal stages may mean resource transfer to the gonads during the reproductive period. Braga (1986), through other authors, showed that values of the condition factor vary according to seasons and are influenced by environmental conditions. The same may be occurring in the environment under study since the floodplain is influenced by many biotic and abiotic factors, which favor the equilibrium of all the species in the ecosystem.

M. intermedia
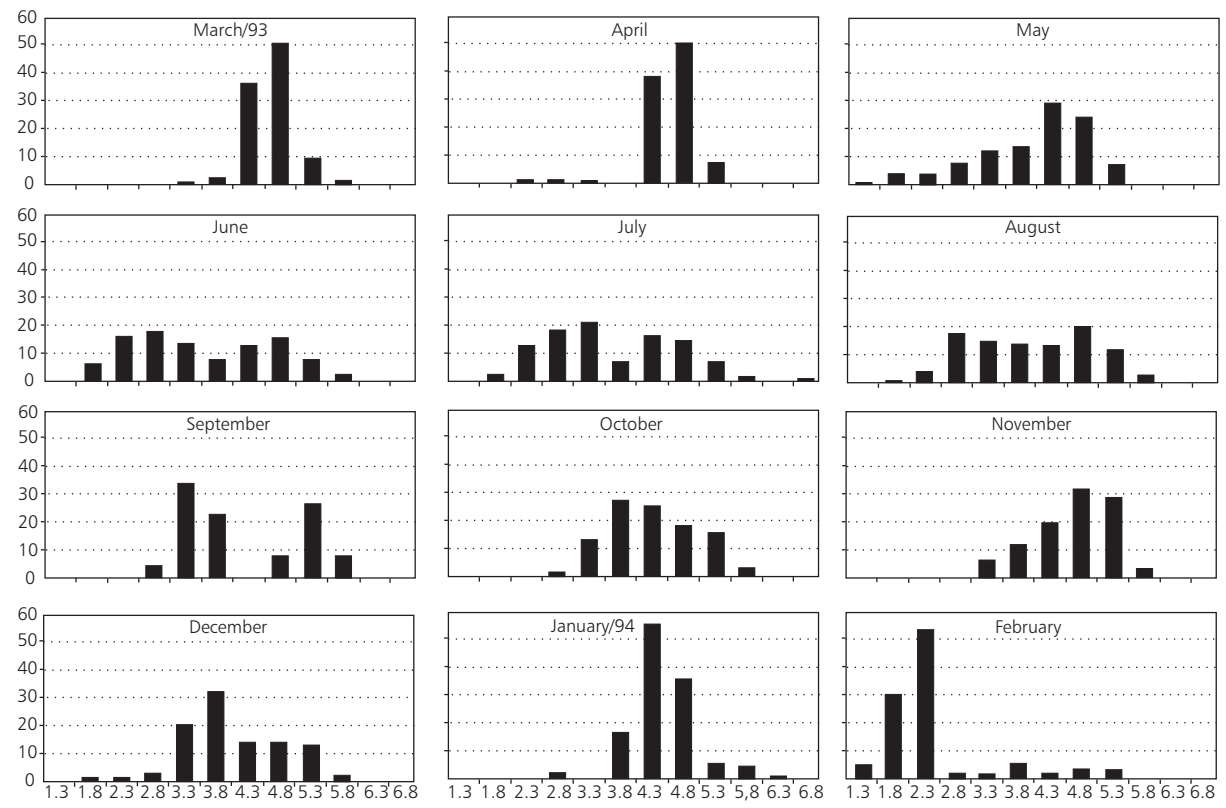

Length class $(\mathrm{cm})$

Fig. 9 - Length frequency distribution of Moenkhausia intermedia in the floodplain the upper Paraná River. 
M. sanctae-filomenae
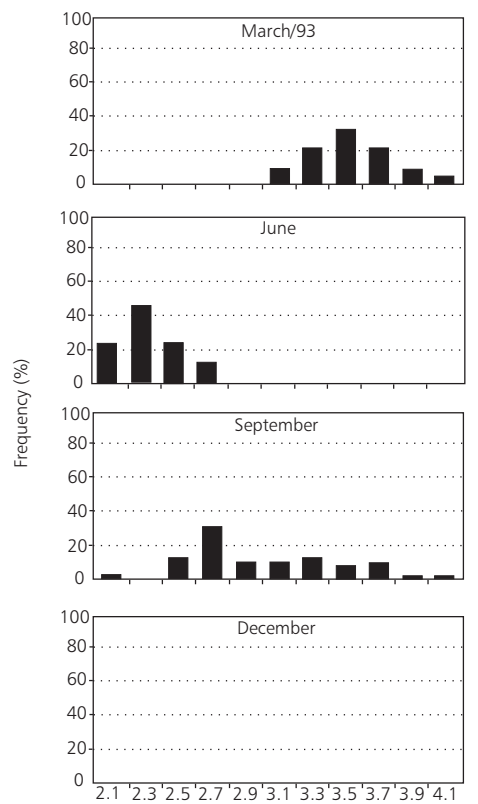

$2.1^{\prime} 2.3^{\prime} 2.5^{\prime} 2.7^{\prime} 2.9^{\prime} 3.1^{\prime} 3.3^{\prime} 3.5^{\prime} 3.7^{\prime} 3.9^{\prime} 4.1$
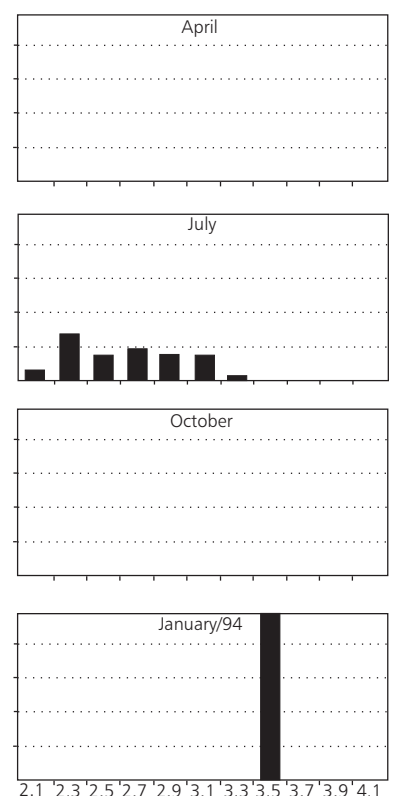

Length class $(\mathrm{cm})$
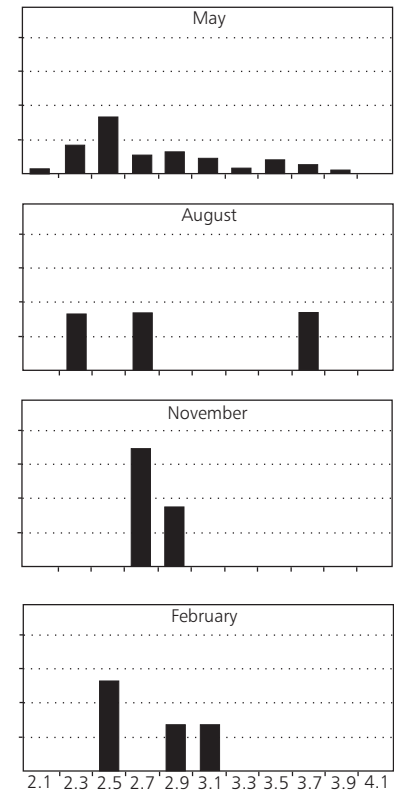

Fig. 10 - Length frequency distribution of Moenkhausia sanctae-filomenae in the floodplain of the upper Paraná River.

R. paranensis
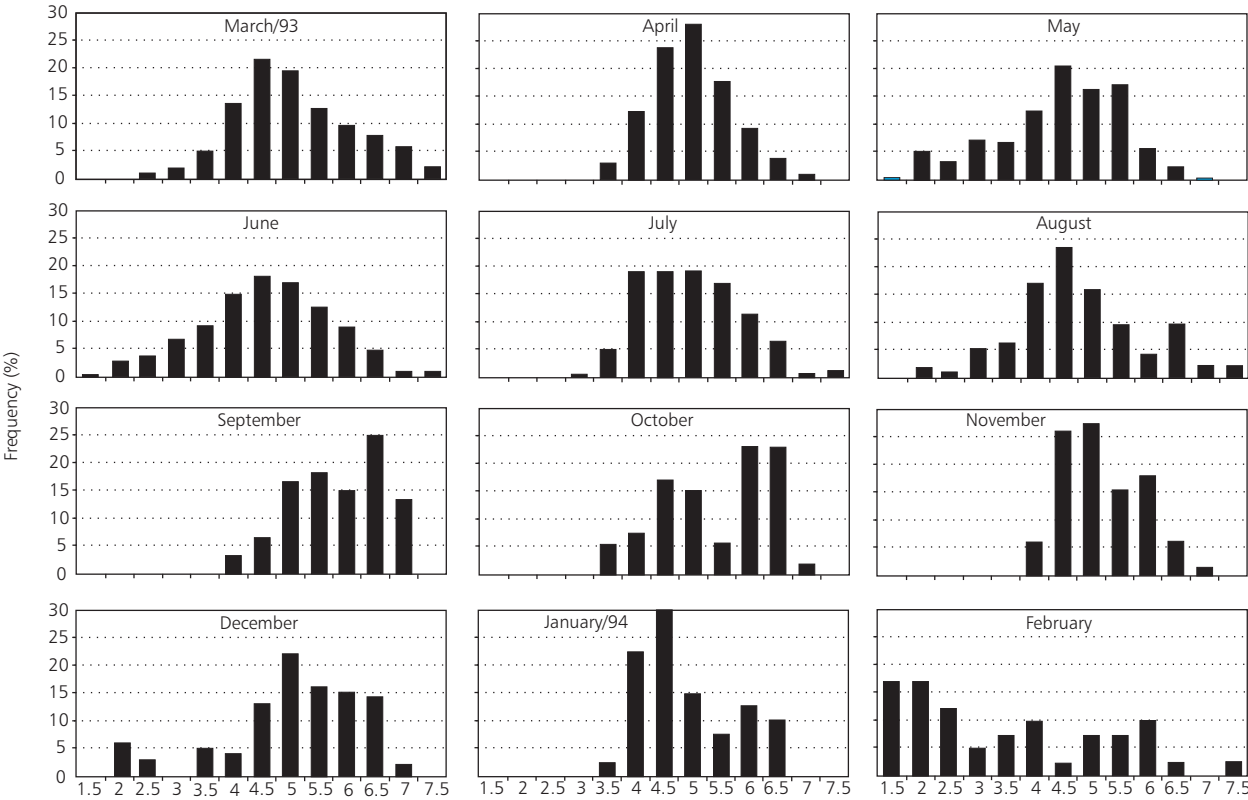

Length class $(\mathrm{cm})$

Fig. 11 - Length frequency distribution of Roeboides paranensis in the floodplain of the upper Paraná River. 
A. altiparanae

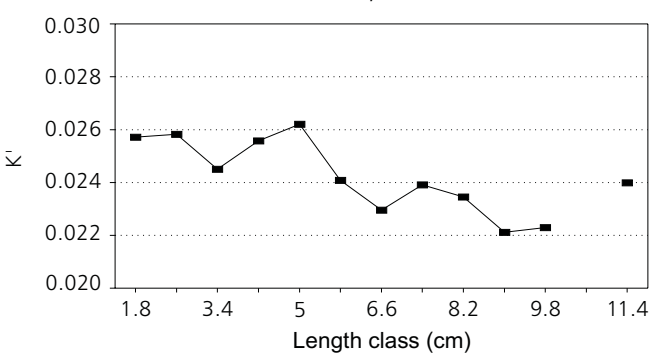

A. schubarti

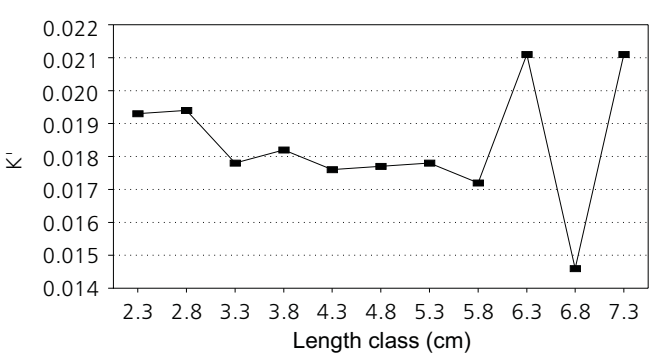

H. callistus

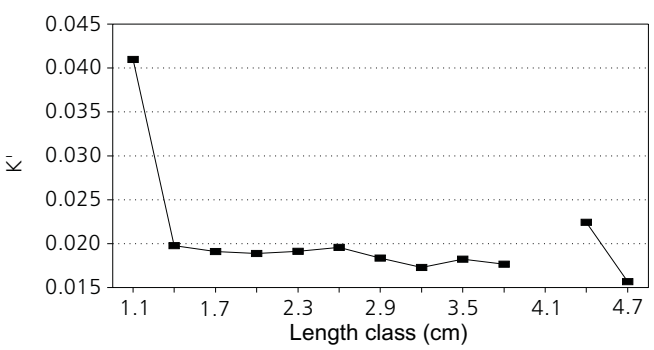

M. intermedia

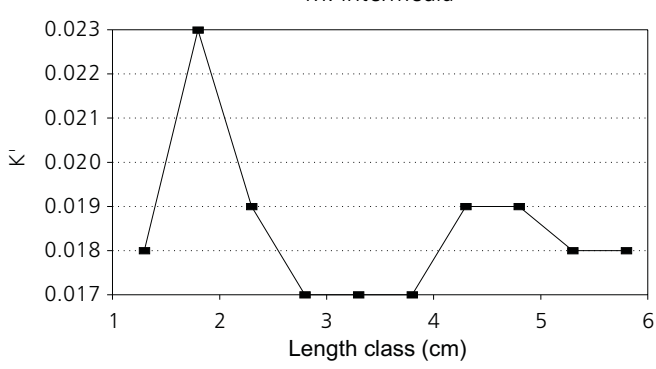

A. nasutus

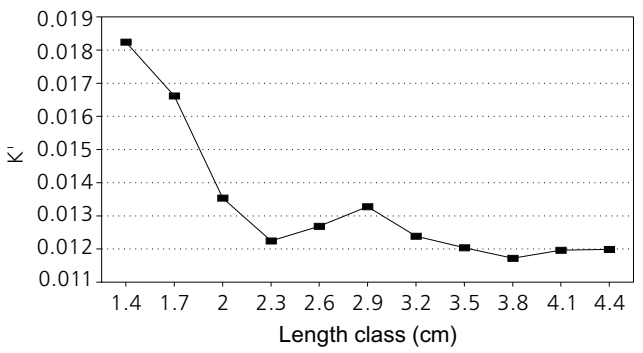

C. notomelas

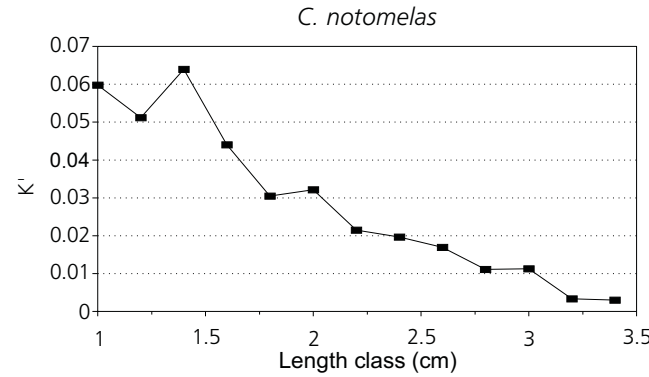

H. marginatus

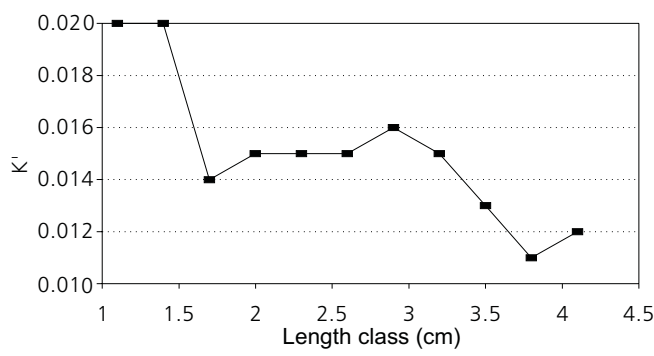

M. sanctae-filomenae

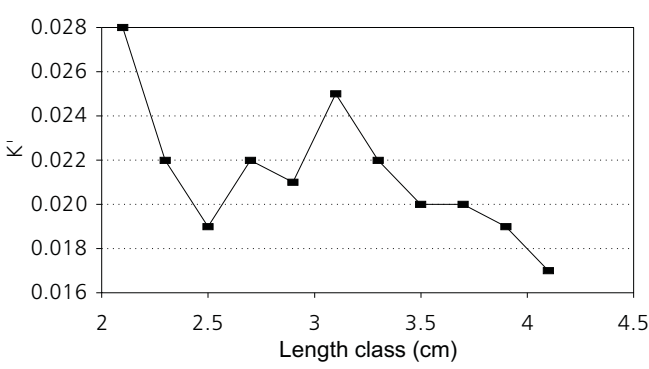

R. paranensis

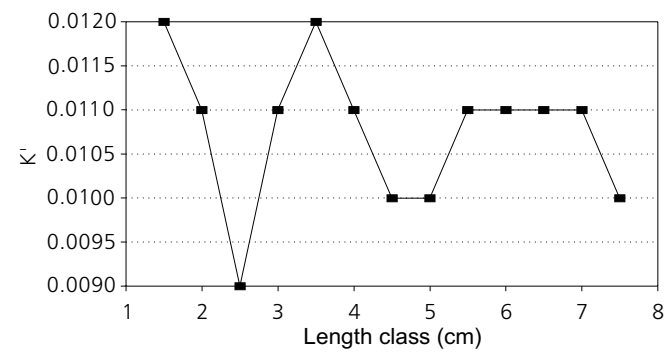

Fig. 12 - Condition factor per length class for the nine Characidae species in the floodplain of the upper Paraná River. 


\section{GENERAL CONSIDERATIONS}

Data on the characid species of the upper Paraná River floodplain show that almost all have prolonged spawning and that recruitment occurs practically throughout the year in this environment. The authors suppose that juveniles of these species have a higher condition factor than mature ones. This has already been observed in studies of various species of marine fish along the Brazilian coast. One may conclude that these foraging species are extremely well adapted to their environment and perform an important role in the trophic balance of this ecosystem.

Acknowledgments - Thanks are due to the PADCT/CIAMB/ UEM program for support this research and to the Research Nucleus in Limnology, Ichthyology and Aquaculture (NUPELIA) of the State University of Maringá for logistic help and infrastructure.

\section{REFERENCES}

ANGELESCU, V., GNERI, F. S. \& NANI, A., 1958, La merluza del mar argentino (biologia e taxonomia). Secr. Mar. Serv. Hidrog. Nav. Publico, H1004: 1-224.

BHATNAGAR, G. K, 1963, On some aspects of the biology of Pontius kolus (Sykes) of the Tungabhadra Reservoir. Indian J. Fish., 10(2): 500-520.

BRAGA, F. M. S., 1986, Estudo entre o fator de condição e relação peso/comprimento para alguns peixes marinhos. Rev. Brasil. Biol., 46(2): 339-346.

BRAGA, F. M. dos S. \& GENNARI FILHO, 1990, Contribuição para o conhecimento da reprodução de Moenkhausia intermedia (Characidae, Tetragonopterinae), na represa de Barra Bonita, rio Piracicaba, São Paulo. Naturalia, 15: 171-188.

BRAGA, F. M. dos S. \& GENNARI FILHO, 1991, Estudos sobre a fecundidade, desova e mortalidade natural de Moenkhausia intermedia (Characidae, Tetragonopterinae), na represa de Barra Bonita, rio Piracicaba, São Paulo, Naturalia, 16: 55-68.

FIGUEIREDO-GARUTI, M. L. \& GARUTI, V., 1991, Fator de condição total e fator de condição somático para fêmeas de Astyanax bimaculatus (Pisces, Characidae), procedentes da região noroeste do Estado de São Paulo, Bacia do rio Paraná. In: IX Encontro Brasileiro de Ictiologia, p. 62 .
LE CREN, E. D., 1951, The length-weight relationship and seasonal cycle in gonad weight and condition in the perch Perca fluviatilis. J. Anim. Ecol., 20(2): 201-219.

LIZAMA, M. de los A. P., AMBRÓSIO, A. M. \& VAZZOLER, A. E. A. de M., 1999, Relação peso-comprimento e estrutura da população de nove espécies da família Characidae na planície de inundação do alto rio Paraná, Brasil. Rev. Bras. Zool., 16(3): 779-788.

MARTINS-JURAS, I. A. G., 1980, Estudo sobre o crescimento de Macrodon ancylodon (Bloch \& Schneider, 1801) capturada nas costas do Rio Grande do Sul (Latitude $29^{\circ} \mathrm{S}$ a $32^{\circ} \mathrm{S}$ ). Dissertação de Mestrado, Universidade de São Paulo, Instituto Oceanográfico, 182p.

RODRIGUES, A. M., SANTOS, R. A. dos, CAMPOS, E. C., DA CÂMARA, J. J. C. \& MANDELLI, J. Jr., 1991, Tipo de desova e fecundidade de Moenkhausia intermedia (Eigenmann, 1908), na represa de Ibitinga, Estado de São Paulo, Brasil. Braz. J. Vet. Res. Anim. Sci., 28(2): 201-206.

RODRIGUES, A. M., SANTOS, R. A. dos, GIAMAS, M. T. D., CAMPOS, E. C. \& CAMARA, J. J. C. da, 1995, Tipo de desova e fecundidade do lambari prata Astyanax schubarti Britski, 1964 (Pisces, Characiformes, Characidae), na represa de Ibitinga, Estado de São Paulo, Brasil. Bol. Inst. Pesca, 22(1): 133-139.

VAZZOLER, A. E. A. de M., 1996, Biologia da reprodução de peixes teleósteos: teoria e prática. EDUEM, SBI, Maringá, 169p.

VAZZOLER, A. E. A. de M. \& BRAGA, F. M. S., 1983, Contribuição para o conhecimento da biologia de Cynoscion jamaicensis (Vaillant \& Bocourt, 1883), na área entre Cabo

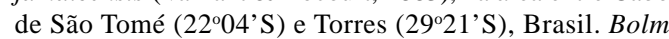
Inst. Oceanogr., 32(2): 125-136.

VAZZOLER, A. E. A. de M. \& VAZZOLER, G., 1965, Relation between condition factor and sexual development in Sardinella aurita (Cuv. \& Val. 1847). Anais Acad. Bras. Ciênc., 37(supl.): 353-359.

WEATHERLEY, A. H., 1972, Growth and ecology of fish populations. Academic Press., London, 293p. 